\title{
KNOWLEDGE, ATTITUDES AND BELIEFS OF OLDER MEN REGARDING HIV AND AIDS IN SOUTH AFRICA
}

\section{Adri Roux, Herman Strydom}

\section{INTRODUCTION}

This article reports on a study done with older men who are affected in many ways by HIV and Aids. The aim of the study was to ascertain the level of knowledge among older men about HIV and Aids, and to what extent daily living has been influenced by the disease. An exploratory design was used for the study, with in-depth interviewing to gain a rich combination of qualitative and quantitative data. Besides providing certain demographic information, participants were interviewed on the impact of general illness in their community, and the impact of HIV and Aids specifically on the individual, the household and the community.

\section{PROBLEM STATEMENT}

HIV and Aids have increasingly become a problem not only in the developed countries, but also in developing countries (Abdool Karim, 2005:31). It is people in the sub-economic and disadvantaged communities who are mostly infected and affected (Evian, 2006:21; Roux, Venter \& Wessels, 2001:33; Strydom, Nogueira \& Roux, 2007:162). South Africa has a serious HIV and Aids pandemic, with millions of its people living with the disease (Dorrington, Bradshaw \& Budlender, 2002:1; Kotze, Roux \& Wessels, 2001:73; Pienaar, 2001:33; Roux, 2002:1; Shishana \& Simbayi, 2002:1).

Of these people, over 6.1 million $(95.1 \%)$ were in the age group 18-62 years (Dorrington et al., 2002:4). According to Stine (2008:284), the prevalence of HIV infection and Aids cases is the highest in South Africa. By the end of 2008 South Africa, with its population of 47 million people, had "over 6.5 million HIV-infected people, the highest incidence of HIV infection in the world" (Stine, 2008:284). These people are especially vulnerable to a number of opportunistic infections that take advantage of a depleted immune system (Whiteside \& Sunter, 2000:2).

The number of people older than 50 who are infected with, and affected by, HIV continues to rise (Orsulic-Jeras, Sheperd \& Britton, 2003:242). Many grandparents, according to Benokraitis (1996:519), have become the "silent saviors" of grandchildren whose parents can't look after them for many reasons or because of problems such as HIV and Aids. According to Delport (2007), Gillwald (2002) and Schönteich (2000), many grandmothers in South Africa become substitute parents for children because of HIV and Aids. Families are affected by HIV and Aids in numerous ways, such as grandparents whose adult children have died of AIDS and they now have to care for the orphaned grandchildren (Strong, De Vault \& Sayad, 1998:432). According to Mason and Linsk (2002:557), "caregivers seemed to acknowledge that family connection extends throughout life and that their responsibility to the children continued until the caregiver either died or was no longer able to care". Some of these grandchildren are also HIV positive. The focus of this article, however, is on the perceptions of HIV and Aids among male grandparents. 


\section{AIM OF THE STUDY}

The aim of the study was to ascertain the level of knowledge, attitudes and beliefs of older males with regard to HIV and Aids, and to what extent daily living has been influenced by the disease.

\section{RESEARCH METHODOLOGY}

An exploratory research design was used in this study (Mitchell \& Jolley, 2001:518-519; Rubin \& Babbie, 2005:123-124), because very few studies have been done regarding HIV and Aids and the aged, and then specifically the older male. Face-to-face interviewing (Neuman, 2006:301-304; Ritchie \& Lewis, 2003:141-144) was done with 51 older men at the local pension pay-point in a semi-urban area of the North-West Province of South Africa. The measuring instrument consisted of a schedule with open and closed-ended questions, thus combining quantitative and qualitative data (Adler \& Clark, 2008:375; Grinnell, 2001:12) in a mixed-methods approach (Alasuutari, Bickman \& Brannen, 2009:1-2; Creswell \& Plano Clark, 2007; Grinnell \& Unrau, 2008:94, 352-353). The concurrent embedded strategy was adopted for this study (Creswell, 2009:214-215) as data were collected simultaneously in one phase. Some questions focused on numbers of participants who have a specific idea on a topic, while other questions focused on the feelings and the real-life experiences of the elderly male.

Questions may be raised about the rather small number of participants in the study. The study does not endeavour in any way to be representative of all older males' perceptions in South Africa, or even for the North-West Province. Pensions are given out on only two days per month and the researchers had to be satisfied with the number of men they could interview on those two days. If more than one month was used to complete the schedules, the same participants might have been interviewed twice. This could have been because there are hundreds of people present at this venue and neither the researchers nor the elderly participants themselves could remember whether the men were interviewed.

An availability sampling technique within the non-probability paradigm was used for the study (Glicken, 2003:178-179; Monette, Sullivan \& DeJongh, 2008:145-146). The researchers asked the very first person meeting the criteria whether they could be interviewed and, if he refused, the next person was asked and so forth. A small room adjacent to the waiting room was used for the interviews. The two interviewers sat in opposite corners of the room so as not to disturb each other. Much time was lost as many potential participants refused to take part, either because they were too shy or too uncomfortable to participate (Sheikh \& Yalom, 1996:135; Strydom 2003a:311), or they were deaf, or simply refused to participate. After each interview the researchers then had to motivate the next participant. The quantitative data analysis was done by way of counting numbers, re-working them into percentages and explaining by way of tables. The qualitative data were delineated into themes and sub-themes, according to Tesch's approach (Poggenpoel, 1998:343-344). Ethical issues such as informed consent, avoidance of deception and subsequent debriefing were taken into consideration throughout the study (Mertens \& Ginsberg, 2009; Strydom, 2005:56-70). 


\section{FINDINGS}

\section{DEMOGRAPHIC DETAILS}

\section{Age}

The youngest participant was 60 , while the oldest participant was 89 years old. The mean age came to 67.4 years. A relatively young group of participants (mean age 69.58 years) was also interviewed in another study at the same venue (Strydom, 2003a:304). In another study by Strydom (2001:102) the same tendency was found, where the largest group of participants was in the age bracket $65-69$ years.

\section{Marital status}

TABLE 1

MARITAL STATUS

\begin{tabular}{|l|c|c|}
\hline Marital status & F & \% \\
\hline Married & 29 & 56.86 \\
\hline Divorced & 2 & 3.92 \\
\hline Living together & 2 & 3.92 \\
\hline Widower & 15 & 29.41 \\
\hline Never married & 3 & 5.88 \\
\hline $\mathbf{N}=$ & $\mathbf{5 1}$ & $\mathbf{1 0 0 . 0 0}$ \\
\hline
\end{tabular}

From Table 1 it can be derived that most of the participants were still married, while the second highest group were widowed.

\section{HOUSING}

TABLE 2

HOUSING

\begin{tabular}{|l|r|r|}
\hline Housing & F & \% \\
\hline Own home & 38 & 74.51 \\
\hline Living with children & 5 & 9.80 \\
\hline Living with family & 7 & 13.73 \\
\hline Living with friends & 1 & 1.96 \\
\hline $\mathbf{N}=$ & $\mathbf{5 1}$ & $\mathbf{1 0 0 . 0 0}$ \\
\hline
\end{tabular}

The overwhelming majority said that they lived in their own homes, which can be anything from a brick house to any form of informal housing or shack; they are normally overcrowded, damp, cold and noisy (Motshedi, 2009:40; Stewart \& Stewart, 1993:124). Very few participants lived with family, children or friends.

\section{Number of people sharing household}

In response to a question on how many people share the household, the following answers were received: 
TABLE 3

NUMBER SHARING HOUSEHOLD

\begin{tabular}{|l|c|c|}
\hline Number of people sharing household & F & \% \\
\hline 1 & 2 & 3.92 \\
\hline $2-3$ & 14 & 27.45 \\
\hline $4-5$ & 16 & 31.37 \\
\hline $6-7$ & 13 & 25.49 \\
\hline $8-9$ & 5 & 9.80 \\
\hline $10+$ & 1 & 1.96 \\
\hline $\mathbf{N}=$ & $\mathbf{5 1}$ & $\mathbf{1 0 0 . 0 0}$ \\
\hline
\end{tabular}

The number of people sharing the household ranges from one to 12 people. The average number of people sharing the household was 4.82. In Strydom's study (2001:103) it was found that $35 \%$ of participants lived in households with six or more people. This figure correlates with the findings of Kotze et al. (2001:77), who found in their study that 4.78 was the average number of people sharing a household in the Potchefstroom Health District. Most of the people sharing the household with the older male are grandchildren who were been informally dumped on the grandparents. The same tendency can be found in the United States regarding African American grandparents (Keigher, Fortune \& Witkin, 2000:288). Acting as caregivers for their grandchildren places older people in a difficult situation as they attempt to offer stability and security to their grandchildren, while struggling to overcome the extra financial burden (Waldrop \& Weber, 2001:461, 467). It was found that more than $60 \%$ of children of older people wanted them to remain in the community and not move into old age homes (Ryke, Ngiba \& Strydom, 2003:144). This makes sense, because many children want their older parents to care for their grandchildren, which they cannot do in old age homes.

\section{Monthly income and total household income}

The only monthly income of the elderly men was R700.00 per month. As far as the total household income is concerned, the following was found.

TABLE 4

TOTAL HOUSEHOLD INCOME

\begin{tabular}{|l|r|r|}
\hline Total income of household & f & \% \\
\hline R501.00 - R750.00 & 24 & 47.06 \\
\hline R751.00 - R1 000.00 & 9 & 17.65 \\
\hline More than R1 200.00 & 18 & 35.29 \\
\hline N= & $\mathbf{5 1}$ & $\mathbf{1 0 0 . 0 0}$ \\
\hline
\end{tabular}

The average total income of households was R791.18 per month. This finding correlates with the figures of Kotze et al. (2001:77), who found the average household income to be R774.50.

\section{People contributing to and supported by household income}

It was found that on average 1.65 persons contributed to the household income, while 5.02 persons were supported by the household income. When one looks at these figures, it is obvious that the pension of R700.00 per month of the older men is in most cases the most 
important, if not the only, income of the household. These figures paint a very bleak picture of the circumstances in which these people are living.

When asked whether their income is adequate, only $3(5.88 \%)$ said yes and $48(94.12 \%)$ said no. Some participants gave more than one response. The motivations of the participants who said that their monthly income was not sufficient can be mentioned as follows:

- "Food is very expensive." 28 (36.84\%)

- "The rent of my house is too high." 18 (23.68\%)

- "Transport is a major problem." 7 (9.21\%)

- "Water and electricity take up all my money." 5 (6.58\%)

- "School fees for my children are too high." 5(6.58\%)

- "I cannot find a job." 5(6.58\%)

- "I go to bed hungry." 4 (5.26\%)

- "I have huge debts." 4 (5.26\%)

The explanations of the few participants who said that their monthly income was adequate can be mentioned as follows:

- "I have enough to live from." $2(3.92 \%)$

- "I eat enough and are happy." 1 (1.96\%)

It is obvious that the elderly men in Potchefstroom live under sub-economic circumstances; poverty is a real problem and the heaviest financial burden is food and house rent. It can be expected of grandparents to baby-sit, to give emotional support and to act as family stabilisers (Belsky, 1999:320), but to have your grandchildren dumped on you is something totally different. In this study it was mostly grandchildren who were supported by the older men. It is obvious that they also had to pay for school fees and clothes for these children. Many cases of the misuse of old people's pension money are reported on, such as family members eating the pensioner's food or stealing his money (Chaka, 2003:3). Strydom (2003b:84-85) discusses the other forms of abuse, such as verbal, physical and emotional. It can be pointed out that older persons should be able to live with dignity and security, and be free of exploitation and abuse (Keigher et al., 2000:5).

\section{IMPACT OF ILLNESS}

\section{Care for ill people}

TABLE 5

CARE FOR ILL PEOPLE

\begin{tabular}{|l|c|c|}
\hline Care for ill people & F & \% \\
\hline Yes & 8 & 15.69 \\
\hline No & 43 & 84.31 \\
\hline $\mathbf{N}=$ & $\mathbf{5 1}$ & $\mathbf{1 0 0 . 0 0}$ \\
\hline
\end{tabular}

From Table 5 it can be derived that the majority of participants, namely (43) $84.31 \%$, do not care for ill people. Of the $8(15.69 \%)$ participants who do care for ill people, 7 care for adults, while only 1 cares for children. When asked about the type of disease, $5(62.5 \%)$ mentioned 
HIV and Aids, $2(25 \%)$ mentioned tuberculosis, while $1(12.5 \%)$ mentioned swollen legs and kidney trouble.

When asked about the impact of caring for these people on their life circumstances, the following responses were given:

- "It is hard - I have to help the ill people." 4 (50\%)

- "It does not bother me." 2 (25\%)

- "I do not know how to help them." 2 (25\%)

At this stage only a few participants take care of ill people. This may change if one takes into account that the elderly men have to support 5.02 people sharing the household. With the increase in deaths caused by HIV and Aids in South Africa, one can predict that in future participants will also have to care for people in the household who suffer from HIV and Aids. According to Dorrington et al. (2002:6), there were 371907 new HIV and Aids cases in the previous year and 262337 AIDS deaths in the previous year. By the year $2000 \mathrm{HIV}$ and Aids had already become already the largest single cause of death, according to Bradshaw and Dorrington (2005:419).

\section{Knowledge of recent deaths}

When asked whether participants knew of people who died recently, the following responses were received:

TABLE 6

KNOWLEDGE OF PEOPLE WHO DIED RECENTLY

\begin{tabular}{|l|r|r|}
\hline People died recently & F & \% \\
\hline Yes & 44 & 86.27 \\
\hline No & 7 & 13.73 \\
\hline N= & $\mathbf{5 1}$ & $\mathbf{1 0 0 . 0 0}$ \\
\hline
\end{tabular}

From Table 6 it can be derived that an overwhelming majority of participants had knowledge of people who died recently. To a follow-up question on the cause of death of these people, 25 (56.82\%) mentioned HIV and Aids, 9 (20.45\%) mentioned tuberculosis, while $10(22.73 \%)$ mentioned misuse of alcohol, an accident or murder as the cause of death.

When asked whether they noticed an increase in the number of funerals, all of the participants answered positively. As a follow-up question, they were asked to what would they attribute the increasing number of deaths. Again the majority attributed the increase in deaths to HIV and Aids, namely 32 (62.75\%), while 7 (13.73\%) mentioned tuberculosis; $12(23.53 \%)$ could not name a cause of death. These figures correlate with the figures of Dorrington et al. (2002:6) and Stine (2008:281-285) on the AIDS deaths.

\section{IMPACT OF HIV AND AIDS}

\section{The term "HIV and Aids"}

Twenty-one (41.18\%) participants mentioned that they do not know what "HIV and Aids" is. The following can be seen as being representative of the $30(58.82 \%)$ responses to the question on the meaning of the term HIV and Aids.

- "You get it from sleeping around." 10 (33.33\%) 
- "All I know is that you do not get better, only worse." 4 (13.33\%)

- "I have heard about AIDS, but do not understand." 4 (13.33\%)

- "It has to do with dirty blood." 3 (10.00\%)

- "It is the big illness." $3(10.00 \%)$

- "These people infect others." 3 (10.00\%)

- "I do not want to know, but I know that people are dying of it." 1 (3.33\%)

- "Today you are healthy, tomorrow you are dead." 1 (3.33\%)

- "This illness comes from the Zimbabwean immigrants." 1 (3.33\%)

All of the participants could mention a simplistic idea on the illness, although there was no real knowledge of the issue. The participants" ignorance on the term "HIV and Aids", correlates with research done by other investigators. In a study done by Roux (2002:84-94) on HIV and Aids patients in the Potchefstroom Health District, and by Sito (2008:37-39) on families affected by HIV and Aids in Thaba-Nchu in the Free State Province, they found that knowledge of HIV and Aids, its causes and the symptoms were inadequate. In research done by Strydom (2000:199) on high school pupils in the North-West Province, he also found that knowledge on HIV and Aids was inadequate.

\section{Preventative strategies}

Twenty (39.22\%) participants had no idea how to avoid contracting HIV and Aids. The other $31(60.78 \%)$ participants suggested the following preventative strategies; this could be seen as representative of the responses on preventative measures:

- You should not sleep around. $16(51.61 \%)$

- The use of condoms can help to avoid the contraction of HIV and Aids. 9 (29.03\%)

- Some medicines can prevent HIV and Aids. 3 (9.68\%)

- Old people cannot get it. $1(3.23 \%)$

- Avoid young people. $1(3.23 \%)$

- You can do nothing to avoid the illness. 1 (3.23\%)

Again participants' views on preventative measures for HIV and Aids are simplistic and show no real knowledge of the issues. According to Shisana and Simbayi (2002:17), the vast majority of participants indicated that they needed further information about the disease, including additional information in relation to sexual abuse, condom negotiation, blood donation, counselling, HIV and Aids symptoms and treatment, caring for orphans and rights.

\section{Knowledge of HIV and Aids-infected people}

A question was put to participants as to whether they know of people who have HIV and Aids. Almost half responded positively, namely 24 (47.06\%), while the other half, namely 27 $(52.94 \%)$ responded negatively. Of the 24 participants who said that they know an infected person, $12(50 \%)$ said that the person is someone in the community, $9(37.5 \%)$ said that it is a friend and only $3(12.5 \%)$ indicated that it is a family member.

Stigmatisation, rejection and discrimination play a very important role worldwide (Keigher et al., 2000:12; Lau, Choi, Tsui \& Su, 2007:1230), but also in Africa and especially in South Africa (Frolich, 2005:354; Roux 2002:300; UNAIDS, 1999:47). This may be one of the reasons why $27(52.94 \%)$ of the elderly men answered that they do not know people with HIV and Aids. Their limited knowledge on HIV and Aids may also be a reason, because they do not 
know what the symptoms of HIV and Aids are. According to the Africa Region of the World Bank (1999) special attention should be paid to developing positive and non-judgemental attitudes towards HIV and Aids among health staff so that they can serve their clients with empathy.

\section{Symptoms of HIV and Aids}

Seventeen $(33.33 \%)$ of the participants could not mention any symptom of HIV and Aids. The other $34(66.66 \%)$ participants mentioned more than one symptom each. The following can be seen as being representative of the qualitative responses to the symptoms of HIV and Aids.

- "These people are terribly thin." 32 (39.51\%)

- "They are very weak." 25 (30.86\%)

- "They cannot eat." 5 (6.17\%)

- "They have mouth sores." 4 (4.94\%)

- "Constant diarrhoea." 4 (4.94\%)

- “A constant cough." 3 (3.70\%)

- "Sores on the face." $3(3.70 \%)$

- "Constant vomiting." 3 (3.70\%)

- "They are feverish." 2 (2.47\%)

The 34 participants who could identify symptoms mentioned 81 symptoms in total. This means that on average each respondent mentioned about two symptoms, which could indicate a fairly good knowledge of HIV and Aids. But on closer examination it becomes clear that it was mainly the first two symptoms that could be identified, namely the weakness and thinness of the patients. The rest of the symptoms were mentioned by small numbers of participants.

The age of patients

TABLE 7

THE MEAN AGE OF INFECTED PEOPLE

\begin{tabular}{|l|c|c|}
\hline The mean age of people who are ill/have died of AIDS & F & \% \\
\hline $11-20$ & 15 & 29.41 \\
\hline $21-30$ & 29 & 56.86 \\
\hline $31-40$ & 7 & 13.73 \\
\hline $\mathbf{N}=$ & $\mathbf{5 1}$ & $\mathbf{1 0 0 . 0 0}$ \\
\hline
\end{tabular}

From Table 7 it can be derived that more than $50 \%$ of participants mentioned the age group 2130 years. The answers of the participants correlate with recent research done by Roux (2002:73-74), Shisana and Simbayi (2002:7) and Stine (2008:266).

\section{Feelings towards infected persons}

This question was firstly asked in an open-ended fashion and afterwards in a closed-ended question. The following responses on their feelings were given to the open-ended question:

- “I feel very sorry for them.” 24 (47.06\%)

- "I would rather not hear about HIV and Aids." 18 (35.29\%)

- "I am confused by this illness." 5 (9.80\%) 
- "I am terribly scared about the consequences of this illness." 3 (5.88\%)

- "I feel overwhelmed." 1 (1.96\%)

The closed-ended responses reflected the following feelings:

TABLE 8

FEELINGS

\begin{tabular}{|l|c|c|c|c|c|c|}
\hline Feelings & \multicolumn{2}{|c|}{ Yes } & \multicolumn{2}{c|}{ No } & f & \% \\
\hline & F & \% & F & \% & $\mathbf{5 1}$ & $\mathbf{1 0 0 . 0 0}$ \\
\hline Sadness & 51 & 0.00 & 0 & 0.00 & 51 & 100.00 \\
\hline Powerlessness & 44 & 86.27 & 7 & 13.73 & 51 & 100.00 \\
\hline Anger & 13 & 25.49 & 38 & 74.51 & 51 & 100.00 \\
\hline Fear & 24 & 47.05 & 27 & 52.95 & 51 & 100.00 \\
\hline Guilt & 5 & 9.80 & 46 & 90.20 & 51 & 100.00 \\
\hline Relief & 6 & 11.76 & 45 & 88.24 & 51 & 100.00 \\
\hline Confusion & 12 & 23.53 & 39 & 76.47 & 51 & 100.00 \\
\hline Disbelief & 2 & 3.92 & 49 & 96.08 & 51 & 100.00 \\
\hline
\end{tabular}

From both the open- and closed-ended responses it can be derived that powerlessness and sadness were the overwhelming feelings of participants, while fear, anger and confusion were also mentioned by a relatively large number of participants.

\section{Impact on the individual}

The impact on the individual was indicated in the following responses:

- "I do not know." 20 (39.22\%)

- "I am scared that I can contract the illness." 12 (23.53\%)

- "I might have to care for a sick family member." $11(21.57 \%)$

- "This illness leaves one with sad emotions." 8 (15.69\%)

Almost $40 \%$ of participants could not think of any impact that HIV and Aids would have on the individual. Fear of contraction of the illness, the fear of having to care for ill family members and sad emotions were mentioned by a fair percentage of participants. HIV and Aids usually cause considerable emotional trauma not only to the infected, but also to the affected and especially the families. The psychological impact of HIV and Aids upon the families usually begins with the disclosure of HIV infection (Bonuck, 1993:79; Ross, 2001:20-21; Roux, 2002:60-63).

\section{Impact on the household}

The following was said on the impact of HIV and Aids on the household:

- "Each and every household will have to care for sick and dying people - the carers will be old people." 32 (62.75\%)

- "The terrible financial burden on households." 12 (23.53\%)

- "I do not know." 4 (7.84\%) 
- "General poverty will set in." 3 (5.88\%)

In this case only a small proportion of participants, namely $8 \%$, could not respond on the impact of HIV and Aids on the household. More than $60 \%$ of participants mentioned the fear that the household would have to care for ill family members and that the carers would be old people. The financial burden that HIV and Aids would bring to households and general poverty were also mentioned by some participants. The impact of HIV and Aids upon the household is enormous. In research done by Tlhojane (2006:21) on poverty-stricken families, the respondents mentioned that "HIV/AIDS makes them feel weak and isolated". Barnett and Blaikie (1992:87) say that the impact of AIDS deaths upon households is unlike other disasters such as drought, famines, earthquakes or even war. One of the most important consequences of HIV and Aids is the financial burden placed upon households, which have to look after families and especially orphans of other families because of AIDS deaths (Barnett \& Blaikie, 1992:104; Weyers, 1990:350-351).

\section{Impact on the community}

The following was said on the impact on the community:

- "Poverty on all levels." 18 (35.29\%)

- "People will not be able to work and earn money." 12 (23.53\%)

- "Every young person will die and only old people will remain behind." 11 (21.57\%)

- "Hospitals will overflow." 10 (19.61\%)

In this case all of the participants could mention something on the impact of HIV and Aids on the community. Poverty on all levels, community members not being able to work, young people dying and the overburdening of the services in the community were mentioned by participants as some of the factors that would impact on the community. HIV and Aids have an enormous impact not only on the individual, but also on the whole community. Pressure because of HIV/AIDS in South Africa is placed upon clinics, hospitals, pension funds, social work organisations, schools, churches as well as industries (Roux, 2002:63). The impact of AIDS deaths is enormous. According to Bradshaw and Dorrington (2005:425-426) and Whiteside and Sunter (2000:11), HIV and Aids-related deaths will outnumber deaths caused by any other illness. According to Shell and Zeitlin (2000:151-152), the average proportion teachers in South Africa who die because of AIDS between the age 30-39 years is $48.30 \%$. The impact on health providers is also traumatic. According to Ross (2001:29), the death of a client can also be extremely traumatic and "exposure to these experiences and issues is likely to elicit existential questioning of one's own mortality on the part of professionals and can further exacerbate the strains of working in this very demanding and challenging field".

\section{GENERAL REMARKS}

This refers to an open section of the schedule where participants could mention anything that they felt they did not have the opportunity to comment on elsewhere. All of the participants made a comment in this section of the schedule and they can be mentioned as follows:

- "We are very ignorant about HIV and Aids." 14 (27.45\%)

- "People should live in the correct relationship with the Lord." 12 (23.53\%)

- "Very worried that nobody is going to remain on earth." 10 (19.61\%)

- "People should say if and when they realize that they have contracted the illness." $9(17.65 \%)$ 
- "It makes me sad to see so many funerals taking place on a daily basis." $6(11.76 \%)$

Almost $30 \%$ of participants mentioned their ignorance about HIV and Aids, while more than $20 \%$ focused on the correct relationship with the Lord. A number of participants also mentioned the dwindling numbers of people on earth, the fact that people should tell if they have contracted the virus, and the number of funerals taking place.

\section{RESEARCHERS' OBSERVATIONS}

The researchers made the following observations:

- Ignorance amongst the older people about HIV and Aids;

- Participants are very sensitive to talk about matters pertaining to sex;

- Very worried about the consequences of the illness;

- Blame young women and immigrants for the spread of the disease;

- They see HIV and Aids as a killer disease.

The researchers also confirmed the ignorance of participants regarding HIV and Aids as was mentioned by participants themselves. A sensitivity about discussing sexual matters and concern about the consequences of the virus were also noticed in participants. There were also some participants who blamed the spread of the illness on young women, probably meaning prostitutes, and immigrants. All participants saw HIV and Aids as a killer disease.

\section{CONCLUSIONS}

- It was found that participants were in the younger elderly group, married, living in their own home, but sharing the household with four other people.

- The participants' personal monthly income was R700.00, with a total monthly household income of R800.00. Five persons were supported by the total income.

- Although there is more than one person in each household who earns money, they do not contribute to the upkeep of the household. The elderly person must then support these people, who are mostly grandchildren. Some even reside in other towns, but are still dependent on their elderly parents.

- The income was totally inadequate, meaning that the participants have been living in subeconomic and poor conditions.

- The majority of participants do not care for ill people at this stage.

- Most of the participants had knowledge of people who died recently.

- Participants could not give an in-depth explanation of the term "HIV and Aids".

- Participants suggested no real preventative strategies against contracting HIV and Aids.

- Most of the participants could name only weakness and thinness as symptoms of HIV and Aids.

- Most of the participants indicated the age group 21-30 years as the age of infected people.

- Powerlessness and sadness were the overwhelming feelings of participants.

- The impact of the disease on the individual was indicated as fear of contracting HIV and Aids, the fear of having to care for ill family members, and sad emotions.

- The impact of HIV and Aids on the household was mentioned as the fear that the household would have to care for ill family members and that the carers would be old people. 
- The impact of the illness on the community was indicated as general poverty, community members not being able to work, the death of young people, and the overburdening of community services.

- Participants indicated their own ignorance of HIV and Aids, which was also confirmed by the researchers.

- The importance of the correct relationship with the Lord was stressed by a substantial number of participants.

- It was also observed that participants were very sensitive about discussing sexual matters and that they blame the disease on women and immigrants.

\section{SUMMARY}

The study aimed to ascertain the level of knowledge of the older male about HIV and Aids and to what extent daily living has been influenced by the disease. Participants had no real knowledge of the symptoms, the term "HIV and Aids" or preventative strategies against the illness. Feelings of powerlessness and sadness were present with most participants. Participants could indicate some factors regarding the impact of HIV and Aids on the individual, the household and the community. Ignorance of the illness was mentioned by participants and noticed by researchers. It was also observed that participants were very sensitive about discussing sexual matters. It can be recommended that a programme should be presented to older people in general in order to empower them with knowledge about HIV and Aids, and develop skills to deal with the disease.

\section{REFERENCES}

ABDOOL KARIM, S.S. 2005. Introduction. In: ABDOOL KARIM, S.S. \& ABDOOL KARIM, Q. (eds) HIV/AIDS in South Africa. Cape Town: Cambridge University Press: 31 36.

ADLER, E.S. \& CLARK, R. 2008. How it's done: an invitation to social research. London: Thomson Wadsworth.

AFRICA REGION OF THE WORLD BANK. 1999. Intensifying action against HIV/AIDS in Africa: responding to a development crisis. Washington: The World Bank.

ALASUUTARI, P., BICKMAN, L. \& BRANNEN, J. 2009. The SAGE Handbook of social research methods. London: Sage Publications.

BARNETT, T. \& BLAIKIE, P. 1992. AIDS in Africa: it's present and future impact. London: Belhaven Press.

BELSKY, J.K. 1999. The psychology of aging: theory, research, and interventions. London: Brooks/Cole Publishing Company.

BENOKRAITIS, N.V. 1996. Marriages and families: changes, choices and constraints. New Jersey: Prentice Hall.

BONUCK, K.A. 1993. AIDS and families: cultural, psychosocial and functional impacts. Social Work in Health Care, 18(2):75-89.

BRADSHAW, D. \& DORRINGTON, R. 2005. AIDS-related mortality in South Africa. In: ABDOOL KARIM, S.S. \& ABDOOL KARIM, Q. (eds) HIV/AIDS in South Africa. Cape Town: Cambridge University Press: 419-429. 
CHAKA, S. 2003. "Stop robbing pensioners” says Chaka. Potchefstroom Herald, 3: Dec. 15. CRESWELL, J.W. 2009. Research design: qualitative, quantitative and mixed methods approaches. London: Sage Publications.

CRESWELL, J.W. \& PLANO CLARK, V.L. 2007. Designing and conducting mixed methods research. London: Sage Publications.

DELPORT, J. 2007. Die ontwikkeling en evaluering van 'n maatskaplike groepwerkintervesieprogram in aanverwante pleegsorgplasings. [The development and evaluation of a social group work intervention programme in kinship foster placements.] Potchefstroom: North-West University. (PhD Thesis)

DORRINGTON, R., BRADSHAW, D. \& BUDLENDER, D. 2002. HIV/AIDS profile in the provinces of South Africa: indicators for 2002. Cape Town: Centre for Actuarial Research, University of Cape Town.

EVIAN, E. 2006. Primary HIV/AIDS care. Houghton: Jacana Media.

FROHLICH, J. 2005. The impact of AIDS on the community. In: ABDOOL KARIM, S.S. \& ABDOOL KARIM, Q. (eds). HIV/AIDS in South Africa. Cape Town: Cambridge University Press: $351-370$.

GILLWALD, C. 2002. Workshop for the Commissioners of Child Welfare. [Online] Available: http://www.doj.gov.za/speech/6march2002.htm [Accessed: 13/06/2006].

GLICKEN, M.D. 2003. Social research: a simple guide. London: Allyn \& Bacon.

GRINNELL, R.M. 2001. Social work research and evaluation: quantitative and qualitative approaches. New York: F.E. Peacock Publishers.

GRINNELL, R.M. \& UNRAU, Y.A. 2008. Social work research and evaluation: foundations of evidence-based practice. London: Oxford University Press.

KEIGHER, S.M., FORTUNE, A.E. \& WITKIN, S.L. 2000. Aging and social work: the changing landscapes. Washington: NASW Press.

KOTZE, G.J., ROUX, A.A. \& WESSELS, C.C. 2001. Die sosio-ekonomiese posisie van MIV/VIGS-pasiënte in die Noordwes Provinsie [The socio-economic position of HIV/AIDS patients in the North-West Province.] Social Work/Maatskaplike Werk, 37(1):72-83.

LAU, J.T.F., CHOI, K.C., TSUI, H.Y. \& SU, X. 2007. Associations between stigmatization toward HIV-related vulnerable groups and similar attitudes toward people living with HIV/AIDS: Branches of the same tree? AIDS Care, 19(10):1230-1240.

MASON, S. \& LINSK, N. 2002. Relative foster parents of HIV-affected children. Child Welfare, 81(4):541-569.

MERTENS, D.M. \& GINSBERG, P.E. 2009. The handbook of social research ethics. Los Angeles: Sage Publications.

MITCHELL, M. \& JOLLEY, J. 2001. Research design explained. London: Harcourt College Publishers.

MONETTE, D.R., SULliVAN, T.J. \& DEJONG, C.R. 2008. Applied social research: a tool for the human services. London: Brooks/Cole Cengage Learning. 
MOTSHEDI, M. 2009. A social work programme for poverty stricken families in rural areas of the Northern Cape Province. Potchefstroom: North-West University. (PhD Thesis)

NEUMAN, W.L. 2006. Social research methods: qualitative and quantitative approaches. London: Pearson Allyn and Bacon.

ORSULIC-JERAS, O., SHEPERD, J.B. \& BRITTON, P.J. 2003. Counseling older adults with HIV/AIDS: a strength-based model of treatment. Journal of Mental Health Counselling, 25(3):233-244.

PIENAAR, A. 2001. 9\% van jeug weet nie van VIGS [9\% of youth do not know of AIDS.] Beeld, 1: Apr. 7.

POGGENPOEL, M. 1998. Data analysis in qualitative research. In: DE VOS, A.S., STRYDOM, H., FOUCHÉ, C.B., POGGENPOEL, M. \& SCHURINK, E.W. (eds) Research at grass roots: a primer for the caring professions: $334-353$.

RITCHIE, J. \& LEWIS, J. 2003. Qualitative research practice: a guide for social science students and researchers. London: SAGE Publications.

ROSS, E. 2001. Images of AIDS: Psychosocial issues for affected individuals, families and professional caregivers. The Social Work Practitioner-Researcher/Die MaatskaplikewerkNavorser-Praktisyn, 13(2):20-32.

ROUX, A.A., VENTER C.S. \& WESSELS, C.C. 2001. A group work programme for HIV/AIDS patients. The Social Work Practitioner-Researcher/Die MaatskaplikewerkNavorser-Praktisyn, 13(2):33-47.

ROUX, A.A. 2002. Evaluering van 'n groepwerkhulpverleningsprogram met MIVpositief/VIGS-pasiënte [Evaluation of a group work empowerment program with HIV positive/AIDS patients.] Potchefstroom: Potchefstroom University for Christian Higher Education. (PhD Thesis)

RUBIN, A. \& BABBIE, E. 2005. Research methods for social work. London: Thomson Brooks/Cole.

RYKE, E., NGIBA, T. \& STRYDOM, H. 2003. Perspectives of elderly blacks on institutional care. Social Work, 39(2):139-148.

SCHÖNTEICH, M. 2000. Age and AIDS: South Africa's time bomb. [Online] Available: http://www.iss.co.za/PUBS/ASR/8nov4/schonteich.html [Accessed: 16/02/2009].

SHEIKH, J.I. \& YALOM, I.D. 1996. Treating the elderly. San Francisco: Jossey-Bass Publishers.

SHELL, R.C.H. \& ZEITLIN, R. 2000. The changes of acquiring HIV/AIDS during schoolgoing years in the Eastern Cape. The Social Work Practitioner-Researcher/Die Maatskaplikewerk- Navorser-Praktisyn, 12(3):139-154.

SHISANA, O. \& SIMBAYI, L. 2002. Nelson Mandela/HSRC study of HIV/AIDS: South African national HIV prevalence, behavioural risks and mass media. Cape Town: Human Sciences Research Council Publishers.

SITO, M.M. 2008. A social group work empowerment programme for families affected by HIV and AIDS from social workers' caseloads. Potchefstroom: North-West University. ( $\mathrm{PhD}$ Thesis) 
STEWART, G. \& STEWART, J. 1993. Social work and housing. Hong Kong: MacMillan Publishers.

STINE, G.J. 2008. AIDS Update 2007. New York: McGraw-Hill Companies Inc.

STRONG, B., DE VAULT, C. \& SAYAD, B.W. 1998. The marriage and family experience: intimate relationships in a changing society. London: Wadsworth Publishing Company.

STRYDOM, C., NOGUEIRA, L. \& ROUX, A.A. 2007. Die houdings en kennis van die plaaswerker-gemeenskap ten opsigte van MIV/VIGS [The attitude and knowledge of the farm worker community towards HIV/AIDS.] Social Work/Maatskaplike Werk, 43(2):162-176.

STRYDOM, H. 2000. The knowledge base of high school pupils in the North West Province on HIV/AIDS. The Social Work Practitioner-Researcher/Die MaatskaplikewerkNavorser-Praktisyn, 12(3):196-207.

STRYDOM, H. 2001. Social development of and services for disadvantaged older persons in Potchefstroom. The Social Work Practitioner-Researcher/Die MaatskaplikewerkNavorser-Praktisyn, 13(2):98-117.

STRYDOM, H. 2003a. Qualitative perceptions of aging of a specific group of black males. The Social Work Practitioner-Researcher/Die Maatskaplikewerk-Navorser-Praktisyn, 15(3):302-322.

STRYDOM, H. 2003b. Perceptions and attitudes towards elder abuse. The Social Work Practitioner-Researcher/Die Maatskaplikewerk-Navorser-Praktisyn, 15(1):76-96.

STRYDOM, H. 2005. Ethical aspects of research in the social sciences and human service professions. In: DE VOS, A.S., STRYDOM, H., FOUCHÉ, C.B. \& DELPORT, C.S.L. (eds). Research at grass roots: for the social sciences and human service professions. Pretoria: Van Schaik Publishers: 56-70.

TLHOJANE, E. 2006. The role of social workers to empower poverty stricken families in rural areas. Potchefstroom: North-West University. (MA(SW) Dissertation)

UNAIDS. 1999. A joint response to AIDS. Geneva: UNICEF.

WALDROP, D.P. \& WEBER, J.A. 2001. From grandparent to caregiver: the stress and satisfaction of raising grandchildren. Families in Society: The Journal of Contemporary Human Services, 82(5):461-472.

WEYERS, M.L. 1990. Die maatskaplike implikasies en impak van VIGS: 'n verkenning [The social implications and impact of AIDS: a reconnaissance.] Koers, 55(3):345-356.

WHITESIDE, A. \& SUNTER, C. 2000. AIDS: the challenge for South Africa. Cape Town: Human \& Rousseau.

Dr Adri Roux and Prof Herman Strydom, School for Psycho-Social Behavioural Sciences: Division Social Work, North-West University (Potchefstroom campus), Potchefstroom, South Africa. 